De dingen moeten dan wel bij naam kunnen worden genoemd, zonder evenwel dat onmiddellijk het (ver)oordelend vingertje wordt geheven. Alleen al in dit opzicht verdient het boek van Van den Heuvel en Ligtermoet een goede ontvangst. Met anderen, die hen in de laatste jaren op andere terreinen van de zuivering (kunstenaars, artsen, advocaten, pers) zijn voorgegaan, hebben zij aangetoond dat voor serieus onderzoek naar de praktijk van de zuivering de archieven niet langer gesloten zijn. Daarom is het te hopen dat het niet bij dit Zeeuwse onderzoek blijft.

J. Bosnians

M. F. Westers, Mr. D. U. Stikker en de na-oorlogse reconstructie van het liberalisme in Nederland. Een zakenman in de politieke arena (Dissertatie Utrecht; Amsterdam: De Bataaf sche Leeuw, 1988, 312 blz., f49,50, ISBN 906707180 3).

Over een belangwekkend man is een belangwekkend boek te schrijven en dat heeft M. F. Westers gedaan. Zijn relaas over mr. D. U. Stikker en de na-oorlogse reconstructie van het liberalisme in Nederland is op datgene wat eerder is verschenen zowel een toevoeging van nieuwe feiten als een handzame ordening van wat al eerder bekend was. De persoon van Stikker wordt ten volle rechtgedaan. De opzet van de studie is aantrekkelijk. Naast uitgebreid hanteren van archieven, literatuur (waarbij ik Scholtens dissertatie over de SER mis) zijn uitvoerige interviews afgenomen en heeft een 'meelees- en commentaargroep' gefunctioneerd. De schrijver voldoet bovendien aan de eerste opdracht van een historicus, hij hanteert een prettig leesbare stijl en vertelt een herkenbaar verhaal. Door de publikatie van dit werk en een aantal studies die in verband met het veertigjarig jubileum van de VVD zijn verschenen is een duidelijke achterstand in de geschiedschrij verij over het na-oorlogse liberalisme in vergelijking met andere politieke stromingen meer dan gecompenseerd.

Het boek van Westers behandelt, na een kenschets van Stikkers persoonlijkheid, achtereenvolgens de oprichting van de Partij van de Vrijheid, een liberale partij die zo niet mocht worden aangeduid, de totstandkoming van de VVD en Stikkers ministerschap, met als gevolg de verslechterende relatie met de VVD en vooral met de politieke aanvoerder, Oud. Terecht besteedt Westers daar in zijn boek grote aandacht aan, maar dan is Stikkers bemoeienis met de reconstructie van het liberalisme ten einde. Zodra Stikker kiest voor het ministerschap is de opmars van Oud een beslissend feit voor de ontwikkeling van het na-oorlogse liberalisme. Westers geeft dat impliciet aan doordat hij enkele keren gewag maakt van het feit dat Stikker overweegt om als partijloze minister van buitenlandse zaken op te treden tengevolge van de contactstoornissen met de Tweede Kamerfractie en vooral met Oud. Stikkers brief van 7 januari 1951 spreekt boekdelen (210), vooral als het gaat om de koersverandering die hij ten opzichte van de voor-oorlogse Liberale Staatspartij had willen realiseren. Dat geldt niet minder voor zijn brief van 6 maart 1951 aan Oud en zijn reactie in april aan Rutgers met betrekking tot zijn herverkiezing als lid van de Verkiezingsraad van de VVD, het feitelijk beslissende college over kandidaten-lijsten bij Kamerverkiezingen (236). Deze opsomming van door Westers gereleveerde feiten is bij lange na niet volledig. Gezien het onderwerp van deze studie had het mijns inziens voor de hand gelegen als de schrijver de conclusie dat op dat ogenblik zijn invloed op de ontwikkeling van het liberalisme in Nederland was geëindigd, duidelijker had verwoord. Het ontdekken van die cesuur wordt nu wel geheel aan de oplettende lezer overgelaten.

Duidelijk wordt dat Stikker, zoals hij ook zelf in zijn memoires vermeldt, geen partijman is 


\section{RECENS IES}

geweest. Zijn intrede in de politiek is door bijzondere omstandigheden veroorzaakt. De dood van Telders en het ontbreken van een duidelijke opvolger in de gelederen van de Liberale Staatspartij. Bovendien was de partijorganisatie gebrekkig en zonder middelen om een verkiezingscampagne te financieren en was de 'coming man' drs. H. A. Korthals in staat om de Bond van Jonge Liberalen achter zich te krijgen. Dat biedt ruimte voor een outsider. Dat werd Stikker. Westers maakt duidelijk hoe zijn werk in de Stichting van de Arbeid en het voorzitterschap van het Centraal Sociaal Werkgevers Verbond hem in de politieke richting hadden gedreven. Zijn benoeming tot lid van de Eerste Kamer in de Voorlopige Staten-Generaal, een van de aangewezen leden om de plaatsen van overleden, dan wel gezuiverde senatoren in te nemen maakt duidelijk dat ook anderen in die na-oorlogse jaren een rol voor hem in het bestuurlijk bestel aannemelijk achtten. Daarmede is Stikker echter allerminst een uitgesproken politieke figuur. Wel heeft hij daarvoor de nodige persoonlijke ijdelheid. Westers is terughoudend bij zijn persoonsbeschrijving, maar noemt terecht dit aspect van Stikkers karakter.

Als Oud begin 1966 kennis neemt van de drukproeven van Stikkers memoires, is zijn aandacht geheel daarop gericht en niet op het partijcongres dat hij als erevoorzitter bijwoont. Met een verwijzing naar het toen zeer de aandacht trekkende boek van Jan Cremer, zegt Oud tegen ieder, die het horen wil: 'Stikker zou zijn memoires beter 'Ik, Dirk Stikker' hebben kunnen noemen'. Dat alles neemt niet weg, dat Westers met grote bekwaamheid heeft duidelijk gemaakt dat Stikker uitzonderlijke kwaliteiten heeft bezeten en daardoor een rol heeft gespeeld die de landsgrenzen verre heeft overschreden. Die rol zou Stikker niet hebben kunnen vervullen als hij partijloos zou zijn gebleven. De opzet van de Partij van de Vrijheid en de totstandkoming van de VVD waren noodzakelijk om Stikker de basis te bieden voor zijn imponerende internationale carrière, te beginnen bij het ministerschap van buitenlandse zaken. Zo heeft de niet-partijman Stikker toch veel te danken aan de partijen die hij mede in het leven heeft geroepen. Westers beschrijft dit zeer boeiend.

Twee korte kritische kanttekeningen wil ik tenslotte maken. De auteur is op bladzijde 184 niet kunnen ontkomen aan de mode om met schema's en modellen te werken. Het voegt feitelijk niets toe aan wat op pagina 183 is uiteengezet. Alleen is de schrijver door de schematisering gedwongen de groep politieke partijen als een geheel in te delen, terwijl er - zoals juist beschreven - fundamentele verschillen zijn.

In de tweede plaats is de zetter niet gelukkig geweest met het bedienen van de spatieknop. Op de bladzijden 18, 20, 71, 72 en 82 vindt de aandachtige lezer voorbeelden, die zonder veel inspanning in grote getale kunnen worden aangevuld. Dit zijn echter nulliteiten in vergelijking met de positieve waarde, die aan dit werk moet worden toegekend. Niet alleen wordt de lezing van harte aanbevolen, men moet hopen dat Westers tot verdere publikaties zal besluiten.

H. J. L. Vonhoff

H. van den Berg, K. van der Veer, Ideologie en massamedia (Dissertatie Uv A; Amsterdam: VU Uitgeverij, 1986, xiii + 594 blz., f75,-, ISBN 906256339 2).

Het omvangrijke boek Ideologie en massamedia is de handelsuitgave van de dissertatie waarop de auteurs als een personele unie aan de Universiteit van Amsterdam zijn gepromoveerd.

Het valt op, dat een aantal keren wordt uitgehaald naar beoefenaars van de in Nederland pas sinds 1985 wettelijk erkende communicatiewetenschap. Op pagina 18, noot 10, wordt wat dit 